\title{
Anti-TNF-Alpha Therapy and Systemic Vasculitis
}

\author{
Pierre-André Jarrot ${ }^{1,2}$ and Gilles Kaplanski ${ }^{1,2}$ \\ ${ }^{1}$ Service de Médecine Interne, Hôpital de la Conception, 147 boulevard Baille, 13005 Marseille, France \\ ${ }^{2}$ INSERM UMR S 1076, UFR Pharmacie, Aix-Marseille-Université, 27 boulevard Jean Moulin, \\ CS 30064, 13385 Marseille, Cedex 5, France
}

Correspondence should be addressed to Gilles Kaplanski; gilles.kaplanski@ap-hm.fr

Received 28 June 2013; Revised 7 January 2014; Accepted 16 January 2014; Published 27 February 2014

Academic Editor: Sophie Desplat-Jégo

Copyright (c) 2014 P.-A. Jarrot and G. Kaplanski. This is an open access article distributed under the Creative Commons Attribution License, which permits unrestricted use, distribution, and reproduction in any medium, provided the original work is properly cited.

TNF- $\alpha$ is a pleiotropic cytokine, which plays a major role in the pathogenesis of numerous autoimmune and/or inflammatory systemic diseases. Systemic vasculitis constitutes a group of rare diseases, characterized by inflammation of the arterial or venous vessel wall, causing stenosis and thrombosis. Treatment of the different type of vasculitis mainly relies on steroids and immunosuppressive drugs. In case of refractory or relapsing diseases, however, a second line of treatment may be required. AntiTNF- $\alpha$ drugs have been used in this setting during the last 15 years with inconsistent results. We reviewed herein the use of anti-TNF$\alpha$ therapy in different kind of vasculitis and concluded that, except for Behcet's disease, this therapeutic option has not demonstrated significant improvement in the treatment of vasculitis.

\section{Introduction}

Tumour necrosis factor alpha (TNF- $\alpha)$ is a pleiotropic cytokine known to play a major role in host defense mechanisms, initiating a beneficial local inflammation which in excess, however, may cause tissue damage [1]. Since 1999 , anti-TNF- $\alpha$ therapy has been used with success in the treatment of patients suffering from rheumatoid arthritis (RA), inflammatory enterocolitis (Crohn's disease and ulcerative colitis), spondyloarthropathies, or psoriasis [2-6]. Randomized international studies have shown the efficacy of five currently commercially available anti-TNF- $\alpha$ molecules. These molecules have also been tested in other autoimmune and inflammatory systemic diseases such as severe vasculitis refractory to conventional treatment but, to date, vasculitis are not included in the list of therapeutic indications of antiTNF- $\alpha$ agents.

Systemic vasculitis is a group of rare diseases characterized by inflammation of the arterial or venous vessel wall, causing stenosis or thrombosis [7]. Initially classified by the size of the vessel involved, primitive vasculitis has been recently reclassified with the introduction of immunological markers in the new Chapel Hill Consensus classification [8]. One can distinguish between large vessels vasculitis (giant cell arteritis (GCA) and Takayasu arteritis (TA)), medium vessels vasculitis (periarteritis nodosa (PAN)), and small vessels vasculitis with immune complex deposits (mixed cryoglobulinemia (MC)) or associated with anti-neutrophil cytoplasmic antibodies (ANCA) (granulomatosis with polyangeitis (GPA) formerly Wegener granulomatosis, eosinophilic granulomatosis with polyangeitis (EGPA) formerly Churg-Strauss disease, and micropolyangeitis (MPA)). In addition, some diseases may affect vessels of variable size (Behcet disease (BD)) [8]. We reviewed the published experience related to the use of anti-TNF- $\alpha$ therapy in these diseases, pointing to the fact that data are relatively rare and often contradictory.

\section{Rationale for the Use of Anti-TNF- $\alpha$ in Vasculitis?}

Two forms of TNF- $\alpha$ are synthesized by activated macrophages and dendritic cells: a transmembrane precursor form ( $26 \mathrm{Kda})$ which is proteolytically cleaved in a soluble form $(17 \mathrm{kda})$ by a TNF- $\alpha$ converting enzyme (TACE) [9]. These two forms bind to two ubiquitous cell surface receptors (TNFR1 and TNFR2) on target cells to initiate proinflammatory genes transcription via the activation of 
Nuclear Factor Kappa B $(\mathrm{NF} \kappa \mathrm{B})$ and Mitogen Activated Protein (MAP) Kinase pathways, as well as proapoptotic genes transcription by the induction of death signal pathways $[1,10]$. TNF- $\alpha$ induces leukoendothelial adhesion via increased expression of various adhesion molecules, such as E-selectin, Intercellular Adhesion Molecule 1 (ICAM-1), and Vascular Adhesion Molecule 1 (VCAM-1), and mediates tissue leukocyte infiltration through chemokine synthesis [11]. TNF- $\alpha$ induces metalloproteinase production and may also participate in endothelial cell death directly via apoptosis or indirectly via neutrophil activation [10].

In addition, TNF- $\alpha$ may play a role in neutrophil "priming" inducing membrane expression of proteinase3 or myeloperoxidase, which are subsequently recognized by ANCA in ANCA-associated vasculitis (AAV) [12]. This cytokine may thus be involved in the pathogenesis of different kind of vasculitis. In addition, binding of anti-TNF$\alpha$ to membrane-associated TNF- $\alpha$ can have an agonistic action, initiating reverse signaling and processes such as apoptosis, cytokine suppression, and cell activation, which could constitute an interesting target in the treatment of vasculitis $[11,13]$. To date, 5 different anti-TNF- $\alpha$ drugs have been developed and are commercially available, 3 consisting in monoclonal antibodies (infliximab (IFX), adalimumab (ADA), and golimumab). IFX is usually used intravenously at 3 to $5 \mathrm{mg} / \mathrm{kg}$ every 8 weeks, and ADA and golimumab are used subcutaneously, $40 \mathrm{mg}$ every 2 weeks for the former and $50 \mathrm{mg}$ once a month for the latter. The fourth available drug is a dimer of a chimeric protein genetically engineered by fusing the extracellular ligand binding domain of human tumour necrosis factor receptor 2 (TNFR2/p75) to the Fc domain of human IgG-1 (etanercept (ETN)) and is used subcutaneously at $25 \mathrm{mg}$ twice a week. The last is a humanised Fab fragment conjugated to polyethylene glycol (certolizumab pegol) but has never been used in vasculitis. Monoclonal antibodies and certolizumab are active on the two molecular forms of TNF $\alpha$, whereas etanercept neutralizes soluble TNF- $\alpha$ only.

\section{Large Vessels Vasculitis}

3.1. Giant Cell Arteritis (GCA). The pathogenesis of GCA seems due to an abnormal cell-mediated immune response taking place in the vessel wall, leading to macrophage activation, giant cell formation, and excess production of interferon gamma [14]. Other proinflammatory cytokines such as IL1, IL-6, and IL-17 may be involved in GCA pathogenesis, whereas experimental data showing the role of TNF- $\alpha$ in this disease are sparse [15]. GCA mostly affects people older than 50 years. Long-term corticosteroids remain the main treatment which is unfortunately commonly complicated by many side effects [16]. Immunosuppressive drugs such as methotrexate (MTX) or aziatropine (AZT) have been used in order to have a steroid sparing effect and in some corticodependent/resistant patients. MTX was tested in 3 prospective studies with contradictory effects, and AZT gave disappointing results in a controlled study enrolling 31 patients [17-20]. Thus, after a few cases showing successful anti-TNF- $\alpha$ treatment in corticodependent GCA patients have been reported, a comparative double blind study was conducted using IFX but was subsequently stopped due to the lack of efficacy on the prevention of relapse [21]. Regarding ETN, a randomized controlled study against placebo was conducted on 17 patients and demonstrated a significant corticosteroid sparing effect after one year, but not for a longer period which was nevertheless the primary end point [22]. Finally, ADA showed no benefit in a prospective study including 70 patients with a primary end point of steroid sparing at week 26 [23]. In view of these different studies, antiTNF- $\alpha$ therapy is not recommended in GCA (Table 1 ).

3.2. Takayasu Arteritis (TA). TA is characterized by inflammation of large vessels, primarily the aorta and its main branches, resulting in anevrysm formation, vascular stenosis, or occlusion, affecting mainly young women. TA is a chronic idiopathic granulomatous panarteritis, resulting from infiltration of the three layers of the vessel wall by macrophages, $\mathrm{T}$ lymphocytes, and natural killer cells [14, 24]. First line treatment consists in high doses of corticosteroids [24]. However, almost $50 \%$ of TA patients demonstrate glucocorticoid resistance or relapsing disease, requiring the addition of immunosuppressive agents such as AZT, cyclophosphamide (CYC), or mycophenolate mofetil (MMF) with inconsistent efficiency [25]. To date, approximately 120 TA patients have been treated with anti-TNF- $\alpha$, mostly with IFX, as a second/third line immunosuppressive therapy. A first open label prospective study involving 15 patients with active or relapsing disease ( 8 treated by infliximab and 7 by etanercept) suggested some therapeutic efficacy which was confirmed by other studies (90\% rate of remission and $60 \%$ for sustained remission) [26-28] (Table 2). Relapses, however, seem to be common after the drug is stopped following remission [27]. In summary, despite the fact that no prospective controlled study has been conducted to date, anti-TNF- $\alpha$ may constitute an interesting therapeutic option in TA patients who have been unable to achieve or maintain remission with steroids alone or common immunosuppressive agents.

\section{Medium Size Vessels Vasculitis}

4.1. Periarteritis Nodosa (PAN). PAN is a rare necrotizing vasculitis complicating hepatitis $B$ virus chronic carriage affecting medium size vessels, whose incidence has declined since the introduction of hepatitis B vaccination and antiviral treatments [29]. The treatment of PAN consists in steroids or immunosuppressive drugs in association with antiviral therapy, according to the gravity of the disease $[29,30]$. In a few case reports, IFX has been used in refractory forms of the disease or because of intolerance of conventional drugs and seems to be effective [31].

\section{Small Size Vessels Vasculitis}

5.1. Mixed Cryoglobulinemia (MC). MC is a small vessel vasculitis involving skin, joints, peripheral nerves, and the kidney, which is mainly associated with hepatitis C, Sjogren's syndrome, or lymphoma [32]. MC is a model of immunecomplex-mediated inflammation of blood vessels and may involve TNF- $\alpha$ [33]. Before the area of anti-CD-20-targeted 
TABLE 1: Randomized controlled trials performed in GCA.

\begin{tabular}{|c|c|c|c|c|c|c|}
\hline References & $\begin{array}{l}\text { Design/anti-TNF- } \alpha \\
\text { therapy }\end{array}$ & $\begin{array}{l}\text { Number of } \\
\text { patients }\end{array}$ & Main objectives & Follow-up & Main results & Side effects \\
\hline Hoffman et al. [21] & $\begin{array}{l}\text { Randomized } \\
\text { controlled trial IFX } \\
\text { versus placebo }\end{array}$ & $\begin{array}{c}44 \text { (28 IFX, } 16 \\
\text { placebo) }\end{array}$ & $\begin{array}{c}\text { Free of relapses } \\
\text { and adverse events } \\
\text { at } 54 \text { weeks }\end{array}$ & 54 weeks & $\begin{array}{c}\text { Stopped early at } \\
\text { week } 22 \text { for lack of } \\
\text { efficacy ( } 43 \% \text { for } \\
\text { IFX versus } 50 \% \text { for } \\
\text { placebo) }\end{array}$ & $\begin{array}{l}\text { Infection: } 71 \% \text { for } \\
\text { IFX versus } 56 \% \text { for } \\
\text { placebo (NS) }\end{array}$ \\
\hline $\begin{array}{l}\text { Martínez-Taboada } \\
\text { et al. [22] }\end{array}$ & $\begin{array}{c}\text { Randomized } \\
\text { controlled trial ETN } \\
\text { versus placebo }\end{array}$ & $\begin{array}{c}17 \text { (8 ETN, } 9 \\
\text { placebo) }\end{array}$ & $\begin{array}{l}\text { To withdraw the } \\
\text { corticosteroid } \\
\text { therapy at } 12 \\
\text { months }\end{array}$ & 12 months & $\begin{array}{l}50 \% \text { for ETN } \\
\text { versus } 22 \% \text { for } \\
\text { placebo (NS) }\end{array}$ & $\begin{array}{l}\text { No differences } \\
\text { between the two } \\
\text { groups }\end{array}$ \\
\hline Mariette et al. [23] & $\begin{array}{c}\text { Randomized } \\
\text { controlled trial ADA } \\
\text { versus placebo }\end{array}$ & $\begin{array}{l}70 \text { (34 ADA, } \\
36 \text { placebo) }\end{array}$ & $\begin{array}{c}\text { Remission and } \\
\text { corticosteroid } \\
<0,1 \mathrm{mg} / \mathrm{kg} / \text { day at } \\
26 \text { weeks }\end{array}$ & 26 weeks & $\begin{array}{l}55,9 \% \text { for } \mathrm{ADA} \\
50 \% \text { for placebo } \\
\text { (NS) }\end{array}$ & $\begin{array}{c}\text { Severe infections: } \\
8,8 \% \text { for ADA } \\
\text { versus } 13,9 \% \text { for } \\
\text { placebo (NS) }\end{array}$ \\
\hline
\end{tabular}

ns: nonsignificant.

TABLE 2: Open label trial performed in TA.

\begin{tabular}{|c|c|c|c|c|c|c|}
\hline References & $\begin{array}{c}\text { Design/anti-TNF- } \alpha \\
\text { therapy }\end{array}$ & $\begin{array}{c}\text { Number of } \\
\text { patients }\end{array}$ & Main objectives & Follow-up & Main results & Side effects \\
\hline $\begin{array}{l}\text { Hoffman et al. } \\
{[26]}\end{array}$ & $\begin{array}{l}\text { Open label trial } \\
\text { IFX/ETN }\end{array}$ & 15 & $\begin{array}{l}\text { Remission and } \\
\text { discontinuation of } \\
\text { corticosteroids }\end{array}$ & 12 months & $\begin{array}{l}67 \% \text { complete remission } \\
27 \% \text { partial remission } \\
(50 \% \text { of glucocorticoid } \\
\text { requirements reduction) }\end{array}$ & $\begin{array}{l}\text { One infusion } \\
\text { reaction to IFX }\end{array}$ \\
\hline
\end{tabular}

biotherapy, only 3 patients with refractory hepatitis C-associated MC treated with anti-TNF- $\alpha$ have been reported with conflicting results, some patients even experiencing severe flare-up of the disease $[34,35]$. At present, the treatment of MC relies on plasma exchange, immunosuppressive drugs, antivirals, and anti-CD-20 therapy (rituximab) [36].

5.2. ANCA-Associated Vasculitis (AAV). AAV is a group of multisystemic diseases characterized by a pauci-immune small vessel vasculitis which includes three different entities: two recently renamed granulomatosis with polyangeitis (GPA), eosinophilic GPA (EGPA), and microscopic polyangeitis (MPA). AAV pathogenesis is consistent with a primary role for neutrophils, which are both the effector cells responsible for endothelial damage via oxygen radical synthesis and enzyme degranulation and the targets of ANCA [37]. Current AAV treatment is based on a six-month induction phase associating high-dose steroids with immunosuppressive drugs such as CYC or rituximab, followed by an 18month maintenance therapy with AZT [38]. However, using these standard treatment protocols, relapses are very common, occurring in $49 \%$ and $35 \%$ of patients with GPA and MPA, respectively $[29,39]$. Moreover, some patients remain refractory to conventional treatments, raising the need for new therapeutic options.

Etanercept was tested initially in an open label trial including 20 relapsing or incompletely controlled GPA and seemed efficient with a 3-point reduction of the Birmingham Vasculitis activating (BVAS) score at 6 months [40]. These results were not confirmed in a larger controlled prospective study including 180 GPA patients [41]. However, it should be noted that this latter study had some design limitations since the two groups were not homogeneous at the baseline, and some patients had localized forms of the disease. Finally, although ETN is known to be of little usefulness in granulomatous disease, only the WGET study provides data confirming that the addition of ETN to usual treatments is ineffective in the maintenance regimen of GPA [41]. Anti-TNF- $\alpha$ monoclonal antibodies have also been tested in refractory AAV patients. The efficiency of infliximab has been observed in prospective observational studies [42, 43]. One multicentric prospective randomized control trial involving 17 patients compared the efficacy of infliximab $(n=9)$ or rituximab $(n=8)$ in association with steroids and immunosuppressive drugs in refractory GPA for a median followup of 30.6 months (+/-15.4). Efficacy of infliximab and/or rituximab to obtain remission at one year was observed, with an advantage for rituximab. During long-term followup, rituximab was also more effective at obtaining and maintaining remission [44]. Recently, 33 patients with active AAV (BVAS > 10) were enrolled in an open prospective trial to study infliximab adjunction to standard therapy in order to obtain remission for a median follow-up of 12 months and demonstrated no benefit with anti-TNF- $\alpha$. However, this was a noncontrolled study and groups lacked homogeneity [45]. The last open label prospective study was conducted with adalimumab associated with standard therapy in refractory AAV with renal involvement. Although no significant gain in response rate was observed, a significant steroid sparing effect was noted [46].

In conclusion, it seems that a short course anti-TNF- $\alpha$ therapy using infliximab may be useful in complement to 
TABLE 3: Open label and randomized controlled trials performed in AAV.

\begin{tabular}{|c|c|c|c|c|c|c|}
\hline References & $\begin{array}{c}\text { Design/anti-TNF- } \alpha \\
\text { therapy }\end{array}$ & $\begin{array}{c}\text { Number of } \\
\text { patients }\end{array}$ & Main objectives & Follow-up & Main results & Side effects \\
\hline Stone et al. [40] & $\begin{array}{l}\text { Open label } \\
\text { trial } \\
\text { ETN }\end{array}$ & $20 \mathrm{GPA}$ & $\begin{array}{c}\text { BVAS at } 6 \\
\text { months } \\
\text { adverse events } \\
\text { during } 6 \text { months }\end{array}$ & 6 months & $\begin{array}{l}3 \text { points Decrease } \\
\text { of BVAS }(P<0,05)\end{array}$ & $\begin{array}{c}\text { Injection site reaction } \\
\text { in } 25 \% \\
95 \% \text { of patients still } \\
\text { taking ETN }\end{array}$ \\
\hline $\begin{array}{l}\text { WGET research } \\
\text { group [41] }\end{array}$ & $\begin{array}{c}\text { Randomized } \\
\text { controlled } \\
\text { trial } \\
\text { ETN versus placebo }\end{array}$ & $\begin{array}{c}180 \text { GPA } \\
(89 \text { ETN, } 91 \\
\text { placebo })\end{array}$ & $\begin{array}{c}\text { Sustained } \\
\text { remission at } 27 \\
\text { months } \\
(\mathrm{BVAS}=0)\end{array}$ & 27 months & $\begin{array}{l}69,7 \% \text { for ETN } \\
\text { versus } 75,3 \% \text { for } \\
\text { placebo (NS) }\end{array}$ & $\begin{array}{c}56,2 \% \text { for ETN versus } \\
57,1 \% \text { for placebo had } \\
\text { a life threatening } \\
\text { event (NS) }\end{array}$ \\
\hline $\begin{array}{l}\text { Morgan } \\
\text { et al. [45] }\end{array}$ & $\begin{array}{l}\text { Open label } \\
\text { trial IFX }\end{array}$ & $\begin{array}{l}33 \text { (22 GPA, } 11 \\
\text { MPA) } \\
\text { (16 IFX, } 17 \\
\text { standard } \\
\text { treatment) }\end{array}$ & $\begin{array}{l}\text { Time to clinical } \\
\text { remission } \\
(B V A S \leq 1)\end{array}$ & 12 months & $\begin{array}{l}\text { No difference } \\
\text { between the two } \\
\text { groups }\end{array}$ & $\begin{array}{c}\text { Infections in } 8 \\
\text { patients for IFX and } 7 \\
\text { for standard } \\
\text { treatment (NS) }\end{array}$ \\
\hline $\begin{array}{l}\text { De Menthon } \\
\text { et al. [44] }\end{array}$ & $\begin{array}{c}\text { Randomized } \\
\text { controlled trial } \\
\text { IFX versus rituximab }\end{array}$ & $\begin{array}{c}17 \text { GPA } \\
\text { (9 IFX, 8 RTX) }\end{array}$ & $\begin{array}{c}\text { CR/PR } \\
\text { at month } 12\end{array}$ & 12 months & $\begin{array}{l}\text { IFX: } 2 \text { CR, } 1 \text { PR } \\
\text { RTX: } 4 \text { CR, } 1 \text { PR }\end{array}$ & $\begin{array}{l}\text { One death in } \\
\text { both groups } \\
\text { (invasive Aspergillosis } \\
\text { for IFX and sudden } \\
\text { death for RTX) }\end{array}$ \\
\hline $\begin{array}{l}\text { Laurino } \\
\text { et al. [46] }\end{array}$ & $\begin{array}{l}\text { Phase } 2 \\
\text { open label } \\
\text { trial ADA }\end{array}$ & $\begin{array}{l}14 \text { (9 GPA, } \\
5 \mathrm{MPA})\end{array}$ & $\begin{array}{l}\text { (i) Induction of } \\
\text { remission } \\
\text { within the first } \\
14 \text { weeks } \\
\text { (ii) time to } \\
\text { remission }\end{array}$ & 17 months & $\begin{array}{l}\text { (i) } 78,5 \% \text { achieved } \\
\text { remission } \\
\text { (ii) Time to } \\
\text { remission } 12 \text { weeks }\end{array}$ & $\begin{array}{c}\text { Infections in } 3 \\
\text { patients ( } 1 \text { mild and } 2 \\
\text { severe including } 1 \\
\text { death) }\end{array}$ \\
\hline
\end{tabular}

NS: Nonsignificant; RTX: rituximab; CP: complete remission; PR: partial remission.

standard regimen in some refractory AAV patients, but the recent published data on the beneficial effects of rituximab for obtaining remission and preventing relapses in MPA and GPA appear much more convincing and may significantly limit the use of anti-TNF- $\alpha$ treatment in AAV in the future $[47,48]$ (Table 3).

\section{Variable Size Vessels Vasculitis}

6.1. Behcet's Disease (BD). $\mathrm{BD}$ is a chronic and relapsing systemic inflammatory disorder characterized by recurrent orogenital ulcerations with possible mucocutaneous, ocular, digestive, vascular, and/or central nervous system involvements. BD pathogenesis is still unclear, but an association between genetic intrinsic factors (HLA-B5) and triggering extrinsic factors is suspected $[49,50]$. First line treatments are adapted to each organ involvement, such as colchicine for mucocutaneous symptoms or combination of steroids and immunosuppressive drugs in case of severe visceral involvement [51]. Some patients however may develop severe and even life-threatening complications despite these standard treatments regimens. The pathogenic role of TNF- $\alpha$ in mediating tissue injury during BD seems to be major, and increased levels of TNF- $\alpha$ and soluble TNF receptors have been found in the peripheral blood of patients with active $\mathrm{BD}$ $[52,53]$.

In 2001, anti-TNF- $\alpha$ treatments were first tested for severe eye involvement showing promising results [54]. A metaanalysis collecting 158 patients included in 14 prospective studies testing infliximab in $\mathrm{BD}$ with ocular lesions refractory to immunosuppressive drugs was realized in 2011. A complete or partial remission was achieved in $65 \%$ and $24 \%$ of patients receiving infliximab, allowing glucocorticoids and immunosuppressive release in about 40\% [55]. A recent open label prospective study enrolling 63 patients receiving infliximab showed similar results after one year of treatment [56]. Interestingly, the improvement was rapidly obtained following the initiation of infliximab [57].

Five open prospective studies demonstrated a beneficial effect of long-term infliximab treatment on the prevention of relapse, maintenance of visual acuity, and immunosuppressive drugs tapering [57-61] (Table 4). Intravitreous injection of infliximab was also tested in refractory uveitis in 15 patients and demonstrated a positive effect [62]. Regarding the use of adalimumab, etanercept, and golimumab, only case reports are currently available but showed beneficial effects in refractory uveitis, [63-65].

Anti-TNF- $\alpha$ treatments were tested in severe refractory cutaneous manifestations, especially etanercept which revealed a significant efficacy compared to placebo on oral ulcers, and nodular lesions [66].

Infliximab in monotherapy was also tested in refractory entero-Behcet during a prospective open trial and showed $100 \%$ improvement on clinical, CT-scan, and colonoscopy [67]. Adalimumab may also be efficient in this kind of patients [68].

In addition, infliximab has been used in $\mathrm{BD}$ affecting the central nervous system (CNS) in open prospective 
TABLE 4: Open label and randomized controlled trials performed in Behcet's uveitis.

\begin{tabular}{|c|c|c|c|c|c|c|}
\hline References & $\begin{array}{l}\text { Design/anti-TNF- } \alpha \\
\text { therapy }\end{array}$ & $\begin{array}{c}\text { Number of } \\
\text { patients }\end{array}$ & Main objectives & Follow-up & Main results & Side effects \\
\hline $\begin{array}{l}\text { Okada } \\
\text { et al. [56] }\end{array}$ & $\begin{array}{c}\text { Open label trial } \\
\text { IFX }\end{array}$ & 63 & $\begin{array}{l}\text { Efficacy of IFX in } \\
\text { the first year of } \\
\text { treatment }\end{array}$ & 12 months & $\begin{array}{c}\text { Improvement in } 69 \% \\
\text { Improvement } \\
\text { somewhat in } 23 \% \\
\text { Unchanged in } 8 \%\end{array}$ & $\begin{array}{c}46 \% \text { of side effects } \\
\text { including } 3 \text { infusion } \\
\text { reactions } \\
\text { No serious side effects }\end{array}$ \\
\hline $\begin{array}{l}\text { Sfikakis } \\
\text { et al. [57] }\end{array}$ & $\begin{array}{l}\text { Open label trial } \\
\text { IFX }\end{array}$ & 25 & $\begin{array}{l}\text { Remission at } \\
\text { day } 28\end{array}$ & 28 days & $\begin{array}{l}89 \% \text { of complete } \\
\text { remission }\end{array}$ & No serious side effects \\
\hline $\begin{array}{l}\text { Ohno } \\
\text { et al. [58] }\end{array}$ & $\begin{array}{c}\text { Open label trial } \\
\text { IFX }\end{array}$ & 12 & $\begin{array}{l}\text { Frequency of } \\
\text { ocular attacks }\end{array}$ & 14 weeks & $\begin{array}{c}\text { Reduction in the } \\
\text { number of relapses } \\
\text { for IFX ( } 5 \mathrm{mg} / \mathrm{kg} \text { and } \\
10 \mathrm{mg} / \mathrm{kg})\end{array}$ & $\begin{array}{l}\text { One case of } \\
\text { tuberculosis } \\
\text { (IFX } 10 \mathrm{mg} / \mathrm{kg} \text { ) }\end{array}$ \\
\hline $\begin{array}{l}\text { Accorinti } \\
\text { et al. [59] }\end{array}$ & $\begin{array}{l}\text { Open label trial } \\
\text { IFX }\end{array}$ & 12 & $\begin{array}{l}\text { Frequency of } \\
\text { ocular attacks }\end{array}$ & 15 months & $\begin{array}{l}\text { 91\% of reduction in } \\
\text { the number of } \\
\text { relapses }\end{array}$ & $\begin{array}{l}33 \% \text { of side effects } \\
\text { including one } \\
\text { tuberculosis and one } \\
\text { herpetic keratitis }\end{array}$ \\
\hline $\begin{array}{l}\text { Tognon } \\
\text { et al. [60] }\end{array}$ & $\begin{array}{l}\text { Open label trial } \\
\text { IFX }\end{array}$ & 7 & $\begin{array}{l}\text { Frequency of } \\
\text { ocular attacks }\end{array}$ & 23 months & $\begin{array}{l}21 \text { to } 6 \text { ocular attacks } \\
\text { observed in the } \\
\text { equivalent period of } \\
\text { time before treatment }\end{array}$ & One infusion reaction \\
\hline $\begin{array}{l}\text { Tugal-Tutkun } \\
\text { et al. [61] }\end{array}$ & $\begin{array}{c}\text { Open label trial } \\
\text { IFX }\end{array}$ & 13 & $\begin{array}{c}\text { Absence of } \\
\text { ocular attacks }\end{array}$ & 6 years & $\begin{array}{c}31 \% \text { remained } \\
\text { attack-free } \\
32 \text { to } 13 \text { ocular attacks } \\
\text { observed in the } \\
\text { equivalent period of } \\
\text { time before treatment }\end{array}$ & $\begin{array}{l}\text { No serious side effects } \\
\text { (7 respiratory tract } \\
\text { infection and one } \\
\text { infusion reaction) }\end{array}$ \\
\hline
\end{tabular}

TABLE 5: Open label and randomized controlled trials performed in BD with cutaneous, intestinal, and central nervous system involvements.

\begin{tabular}{|c|c|c|c|c|c|c|}
\hline References & $\begin{array}{c}\text { Type of involvement/ } \\
\text { design/anti-TNF- } \alpha \\
\text { therapy }\end{array}$ & $\begin{array}{c}\text { Number of } \\
\text { patients }\end{array}$ & Main objectives & Follow-up & Main results & Side effects \\
\hline $\begin{array}{l}\text { Melikoglu et al. } \\
\text { [66] }\end{array}$ & $\begin{array}{c}\text { Cutaneous/ } \\
\text { randomized } \\
\text { controlled trial/ } \\
\text { ETN versus placebo }\end{array}$ & $\begin{array}{c}40 \\
(20 \mathrm{ETN} / \\
20 \text { placebo })\end{array}$ & $\begin{array}{l}\text { (i) Pathergy response } \\
\text { and monourate } \\
\text { sodium status } \\
\text { (ii) frequencies of } \\
\text { mucocutaneous } \\
\text { manifestations }\end{array}$ & 4 weeks & $\begin{array}{l}\text { (i) No differences } \\
\text { between the two groups } \\
\text { (ii) decrease of } \\
\text { frequency of } \\
\text { mucocutaneous } \\
\text { manifestations }\end{array}$ & $\begin{array}{c}\text { No serious side } \\
\text { effects }\end{array}$ \\
\hline Iwata et al. [67] & $\begin{array}{c}\text { Entero-Behcet/ } \\
\text { open label trial/ } \\
\text { IFX } \\
\end{array}$ & 10 & $\begin{array}{c}\text { Clinical } \\
\text { manifestations } \\
\text { CT-scan } \\
\end{array}$ & 12 months & $\begin{array}{l}\text { Rapid and dramatic } \\
\text { improvement } \\
\text { for all the patients }\end{array}$ & $\begin{array}{c}\text { No serious side } \\
\text { effects }\end{array}$ \\
\hline $\begin{array}{l}\text { Kikuchi et al. } \\
\text { [69] }\end{array}$ & $\begin{array}{l}\text { Neuro-Behcet/ } \\
\text { open label trial/ } \\
\text { IFX }\end{array}$ & 5 & $\begin{array}{c}\text { Clinical } \\
\text { manifestations } \\
\text { brain magnetic } \\
\text { resonance imaging }\end{array}$ & 24 weeks & $\begin{array}{c}\text { Improvement in } 3 \\
\text { patients }\end{array}$ & $\begin{array}{c}\text { One } \\
\text { pneumocystis } \\
\text { pneumonia }\end{array}$ \\
\hline $\begin{array}{l}\text { Giardina et al. } \\
{[70]}\end{array}$ & $\begin{array}{c}\text { Neuro-Behcet/ } \\
\text { open label trial/ } \\
\text { IFX }\end{array}$ & 21 & $\begin{array}{c}\text { Clinical } \\
\text { manifestations } \\
(\mathrm{CR} / \mathrm{PR})\end{array}$ & 54 weeks & $\begin{array}{l}85 \% \text { of } \mathrm{CR} \\
9 \% \text { of } \mathrm{PR}\end{array}$ & $\begin{array}{c}\text { No serious side } \\
\text { effects }\end{array}$ \\
\hline
\end{tabular}

CR: complete remission; PR: partial remission.

studies and was almost always successful [69, 70]. These patients were refractory to high-dose steroids combined with various immunosuppressive drugs and demonstrated major improvement or stabilization of their symptoms. Long-term remission (6-18 months) after discontinuation of infliximab therapy was noted in $75 \%$ of patients $[69,70]$ (Table 5 ). Adalimumab and etanercept have also been tried in case reports of
$\mathrm{BD}$ with CNS involvement with a favorable outcome [71, 72]. In case of a first anti-TNF- $\alpha$ failure in refractory $\mathrm{BD}$, a switch of molecule was made in up to $25 \%$ of cases with a $70 \%$ improvement [73].

In summary, infliximab seems effective in induction treatment and relapse prevention in severe BD refractory to glucocorticoids or immunosuppressive drugs, especially 
in case of eye involvement. It could also be an alternative therapy to immunosuppressive drugs in case of central nervous system or gastrointestinal manifestations. Nevertheless, the main limitation of the present analysis is that most information originated from limited cases or noncontrolled studies, strongly raising the need for properly randomized controlled clinical trials.

\section{Safety and Tolerance of TNF-Alpha Blockade}

In vasculitis, anti-TNF- $\alpha$ are often prescribed as second/third line treatments in patients already immunocompromised by long-term use of glucocorticoids and immunosuppressive drugs. Despite this fact, side effects have been reported up to $46 \%$ and are mostly moderate. The literature review suggests that these drugs are rather safe, in agreement with what is known in RA and spondyloarthropathy $[56,74]$.

Patients treated with anti-TNF- $\alpha$ are prone to develop soon after initiation bacterial and viral infections mostly affecting respiratory or urinary tracts and cutaneous or soft tissues. Furthermore, reactivation of latent tuberculosis or extrapulmonary forms of this infection is another wellknown threat [75-81].

The role of anti-TNF- $\alpha$ therapy in carcinogenesis and tumor progression remains a matter of controversy. A large study assessed the risk of cancer in a RA cohort treated with anti-TNF- $\alpha$ and showed a relative risk (RR) of 1.00 (95\% CI: 0.86-1.15) compared to the biotherapy naive RA cohort. RR did not increase with longer exposure or with the cumulative duration of active anti-TNF- $\alpha$ therapy during a 6year follow-up period [82]. Regarding the risk of hemopathy, infliximab and etanercept were not associated with the occurrence of lymphoma in a study involving 19,000 patients with RA [83]. One observational study, however, showed a positive association between anti-TNF- $\alpha$ therapy in RA and nonmelanoma skin cancers with a follow-up period of 3 years [84]. In vasculitis, especially AAV, an unusually high frequency of solid cancer was reported in a randomized controlled trial that evaluated etanercept for maintenance of remission in 180 patients with GPA. But all the patients $(n=6)$ who developed cancer also received standard therapy associating MTX or CYC, which are known to be involved in cancerogenesis [44]. Without large specific epidemiological studies, caution is however advised.

Besides infection and malignancy, anti-TNF- $\alpha$ treatments can induce acute infusion reaction, which may lead to discontinuation of the treatment. Anti-TNF therapy may also favor antinuclear antibodies appearance which are, however, weakly associated with clinical symptoms $[85,86]$. Other extending complications are allocated to anti-TNF$\alpha$ treatments, such as the occurrence of demyelinating and sarcoid-like granulomatous diseases [87].

\section{Conclusion}

Anti-TNF- $\alpha$ treatments in vasculitis did not demonstrate the same efficacy as in other inflammatory diseases such as RA.
Nevertheless, anti-TNF- $\alpha$ should be used in the treatment of BD refractory to immunosuppressive drugs, especially in case of ocular, CNS, or digestive tract involvement. Some interesting data are also available for the use of anti-TNF$\alpha$ treatments in refractory AAV, but the recent reports on rituximab efficacy in these diseases and the relative innocuity of this drug may limit the use of anti-TNF- $\alpha$ in these diseases, in the future. In both $\mathrm{BD}$ and $\mathrm{AAV}$, an anti-TNF monoclonal antibody especially infliximab should be preferred to etanercept. In addition, physicians must be aware of the risk of infection using these drugs, especially in patients already immunocompromised by previous treatments. Regarding other vasculitis, published data are not in favor of efficiency of anti-TNF- $\alpha$ which, therefore, should not be used.

\section{Conflict of Interests}

The authors declare that there is no conflict of interests regarding the publication of this paper.

\section{References}

[1] D. Tracey, L. Klareskog, E. H. Sasso, J. G. Salfeld, and P. P. Tak, "Tumor necrosis factor antagonist mechanisms of action: a comprehensive review," Pharmacology \& Therapeutics, vol. 117, no. 2, pp. 244-279, 2008.

[2] D. H. Present, P. Rutgeerts, S. Targan et al., "Infliximab for the treatment of fistulas in patients with Crohn's disease," The New England Journal of Medicine, vol. 340, no. 18, pp. 1398-1405, 1999.

[3] P. Rutgeerts, W. J. Sandborn, B. G. Feagan et al., "Infliximab for induction and maintenance therapy for ulcerative colitis," The New England Journal of Medicine, vol. 353, no. 23, pp. 24622476, 2005.

[4] M. A. Dentener and E. F. M. Wouters, "Tumor necrosis factor inhibitors for rheumatoid arthritis," The New England Journal of Medicine, vol. 355, no. 19, pp. 2047-2048, 2006.

[5] S. Schnarr, J. G. Kuipers, and H. Zeidier, "Anti tumour necrosis factor (TNF-alpha) in undiferenciated spondyloarthropathy," Clinical Experimental Rheumatology, vol. 6, no. 20, supplement 28, pp. 126-129, 2002.

[6] U. Chaudhari, P. Romano, L. D. Mulcahy, L. T. Dooley, D. G. Baker, and A. B. Gottlieb, "Efficacy and safety of infliximab monotherapy for plaque-type psoriasis: a randomised trial," The Lancet, vol. 357, no. 9271, pp. 1842-1847, 2001.

[7] L. Guillevin, C. Pagnoux, and P. Guilpain, "Classification of systemic vasculatides," Presse Médicale, vol. 36, no. 5, part 2, pp. 845-853, 2007.

[8] R. Abdulkader, S. E. Lane, D. G. Scott, and R. A. Watts, "Classification of vasculitis : EMA classification using CHCC 2012 definitions," Annals of the Rheumatic Diseases, vol. 72, no. 11, article 1888, 2013

[9] A. J. H. Gearing, P. Beckett, M. Christodoulou et al., "Processing of tumour necrosis factor- $\alpha$ precursor by metalloproteinases," Nature, vol. 370, no. 6490, pp. 555-557, 1994.

[10] M. Aringer and J. S. Smolen, "SLE-complex cytokine effects in a complex autoimmune disease: tumor necrosis factor in systemic lupus erythematosus," Arthritis Research and Therapy, vol. 5, no. 4, pp. 172-177, 2003. 
[11] F. Mackay, H. Loetscher, D. Stueber, G. Gehr, and W. Lesslauer, "Tumor necrosis factor $\alpha$ (TNF- $\alpha)$-induced cell adhesion to human endothelial cells is under dominant control of one TNF receptor type, TNF- R55," The Journal of Experimental Medicine, vol. 177, no. 5, pp. 1277-1286, 1993.

[12] D. J. Radford, J. M. Lord, and C. O. S. Savage, “The activation of the neutrophil respiratory burst by anti-neutrophil cytoplasm autoantibody (ANCA) from patients with systemic vasculitis requires tyrosine kinases and protein kinase C activation," Clinical and Experimental Immunology, vol. 118, no. 1, pp. 171$179,1999$.

[13] H. Mitoma, T. Horiuchi, H. Tsukamoto et al., "Mechanisms for cytotoxic effects of anti-tumor necrosis factor agents on transmembrane tumor necrosis factor $\alpha$-expressing cells: comparison among infliximab, etanercept, and adalimumab," Arthritis \& Rheumatism, vol. 58, no. 5, pp. 1248-1257, 2008.

[14] C. M. Weyand and J. J. Goronzy, "Medium- and large-vessel vasculitis," The New England Journal of Medicine, vol. 349, no. 2, pp. 160-169, 2003.

[15] S. Visvanathan, M. U. Rahman, G. S. Hoffman et al., "Tissue and serum markers of inflammation during the follow-up of patients with giant-cell arteritis-a prospective longitudinal study," Rheumatology, vol. 50, no. 11, pp. 2061-2070, 2011.

[16] G. G. Hunder, "Epidemiology of giant-cell arteritis," Cleveland Clinic Journal of Medicine, vol. 69, supplement 2, pp. SII79SII82, 2002.

[17] J. A. Jover, C. Hernández-García, I. C. Morado, E. Vargas, A. Bañares, and B. Fernàndez-Gutiérrez, "Combined treatment of giant-cell arteritis with methotrexate and prednisone: a randomized, double-blind, placebo-controlled trial," Annals of Internal Medicine, vol. 134, no. 2, pp. 106-114, 2001.

[18] R. F. Spiera, H. J. Mitnick, M. Kupersmith et al., "A prospective, double-blind, randomized, placebo controlled trial of methotrexate in the treatment of giant cell arteritis (GCA)," Clinical and Experimental Rheumatology, vol. 19, no. 5, pp. 495501, 2001.

[19] G. S. Hoffman, M. C. Cid, D. B. Hellmann et al., "A multicenter, randomized, double-blind, placebo-controlled trial of adjuvant methotrexate treatment for giant cell arteritis," Arthritis \& Rheumatism, vol. 46, no. 5, pp. 1309-1318, 2002.

[20] M. de Silva and B. L. Hazleman, "Azathioprine in giant cell arteritis/polymyalgia rheumatica: a double-blind study," Annals of the Rheumatic Diseases, vol. 45, no. 2, pp. 136-138, 1986.

[21] G. S. Hoffman, M. C. Cid, K. E. Rendt-Zagar et al., "Infliximab for maintenance of glucocorticosteroid-induced remission of giant cell arteritis a randomized trial," Annals of Internal Medicine, vol. 146, no. 9, pp. 621-630, 2007.

[22] V. M. Martínez-Taboada, V. Rodríguez-Valverde, L. Carreño et al., "A double-blind placebo controlled trial of etanercept in patients with giant cell arteritis and corticosteroid side effects," Annals of the Rheumatic Diseases, vol. 67, no. 5, pp. 625-630, 2008.

[23] X. Mariette, E. Hachulla, C. Larroche et al., "Results of randomized controlled study of adalimumab for steroid sparing in patient with giant cell arteritis and corticosteroid side effects," Arthritis \& Rheumatism, vol. 63, p. S589, 2011.

[24] G. S. Kerr, C. W. Hallahan, J. Giordano et al., "Takayasu arteritis," Annals of Internal Medicine, vol. 120, no. 11, pp. 919929, 1994.

[25] G. S. Hoffman, "Treatment of resistant Takayasu's arteritis," Rheumatic Disease Clinics of North America, vol. 21, no. 1, pp. 73-80, 1995.
[26] G. S. Hoffman, P. A. Merkel, R. D. Brasington, D. J. Lenschow, and P. Liang, "Anti-tumor necrosis factor therapy in patients with difficult to treat Takayasu arteritis," Arthritis \& Rheumatism, vol. 50, no. 7, pp. 2296-2304, 2004.

[27] E. S. Molloy, C. A. Langford, T. M. Clark, C. E. Gota, and G. S. Hoffman, "Anti-tumour necrosis factor therapy in patients with refractory Takayasu arteritis: long-term follow-up," Annals of the Rheumatic Diseases, vol. 67, no. 11, pp. 1567-1569, 2008.

[28] J. Schmidt, T. A. Kermani, A. K. Bacani, C. S. Crowson, E .L. Matteson, and K. J. Warrington, "Tumor necrosis factor inhibitors in patients with Takayasu arteritis: experience from a referral center with long-term followup," Arthritis Care Research, vol. 64, no. 7, pp. 1079-1083, 2012.

[29] M. Gayraud, L. Guillevin, P. le Toumelin et al., "Long term follow up of polyarteritis nodosa, microscopic polyangiitis and Churg-Strauss syndrome : analysis of four prospective trials including 278 patients," Arthritis \& Rheumatism, vol. 44, no. 3, pp. 666-675, 2001.

[30] L. Guillevin, A. Mahr, P. Callard et al., "Hepatitis B virusassociated polyarteritis nodosa: clinical characteristics, outcome, and impact of treatment in 115 patients," Medicine, vol. 84, no. 5, pp. 313-322, 2005.

[31] K. Wu and D. Throssell, "A new treatment for polyarteritis nodosa," Nephrology Dialysis Transplantation, vol. 21, no. 6, pp. 1710-1712, 2006.

[32] O. Trejo, M. Ramos-Casals, M. García-Carrasco et al., "Cryoglobulinemia: study of etiologic factors and clinical and immunologic features in 443 patients from a single center," Medicine, vol. 80, no. 4, pp. 252-262, 2001.

[33] G. Kaplanski, V. Marin, T. Maisonobe et al., "Increased soluble p55 and p75 tumour necrosis factor- $\alpha$ receptors in patients with hepatitis C-associated mixed cryoglobulinaemia," Clinical and Experimental Immunology, vol. 127, no. 1, pp. 123-130, 2002.

[34] P. Bartolucci, J. Ramanoelina, P. Cohen et al., "Efficacy of the anti-TNF- $\alpha$ antibody infliximab against refractory systemic vasculitidis: an open pilot study on 10 patients," Rheumatology, vol. 41, no. 10, pp. 1126-1132, 2002.

[35] M.-O. Chandesris, S. Gayet, N. Schleinitz, B. Doudier, J.R. Harlé, and G. Kaplanski, "Infliximab in the treatment of refractory vasculitis secondary to heptitis C-associated mixed cryoglobulinaemia," Rheumatology, vol. 43, no. 4, pp. 532-533, 2004.

[36] B. Terrier and P. Cacoub, "Cryoglobulinemia vasculitis: an update," Current Opinion in Rheumatology, vol. 25, no. 1, pp. 1018, 2013.

[37] V. C. Primo, S. Marusic, C. C. Franklin et al., "Anti-PR3 immune responses induce segmental and necrotizing glomerulonephritis," Clinical and Experimental Immunology, vol. 159, no. 3, pp. 327-337, 2010.

[38] L. Guillevin, "How to treat systemic necrotizing vasculitides?" Presse Médicale, vol. 41, no. 10, pp. 1024-1030, 2012.

[39] G. S. Hoffman, G. S. Kerr, R. Y. Leavitt et al., "Wegener granulomatosis: an analysis of 158 patients," Annals of Internal Medicine, vol. 116, no. 6, pp. 488-498, 1992.

[40] J. H. Stone, M. L. Uhlfelder, D. B. Hellmann, S. Crook, N. M. Bedocs, and G. S. Hoffman, "Etanercept combined with conventional treatment in Wegener's granulomatosis : a six-month open-label trial to evaluate safety," Arthritis \& Rheumatism, vol. 44, no. 5, pp. 1149-1154, 2001. 
[41] Wegener's Granulomatosis Etanercept Trial (WGET) Research Group, "Etanercept plus standard therapy for Wegener's granulomatosis," The New England Journal of Medicine, vol. 352, no. 4, pp. 351-361, 2005.

[42] P. Lamprecht, J. Voswinkel, T. Lilienthal et al., "Effectiveness of TNF- $\alpha$ blockade with infliximab in refractory Wegener's granulomatosis," Rheumatology, vol. 41, no. 11, pp. 1303-1307, 2002.

[43] A. D. Booth, H. J. Jefferson, W. Ayliffe, P. A. Andrews, and D. R. Jayne, "Safety and efficacy of TNF $\alpha$ blockade in relapsing vasculitis," Annals of the Rheumatic Diseases, vol. 61, no. 6, article 559, 2002.

[44] M. de Menthon, P. Cohen, C. Pagnoux et al., "Infliximab or rituximab for refractory Wegener's granulomatosis: long-term follow-up. A prospective randomised multicentre study on 17 patients," Clinical and Experimental Rheumatology, vol. 29, no. 1, pp. S63-S71, 2011.

[45] M. D. Morgan, M. T. Drayson, C. O. S. Savage, and L. Harper, "Addition of infliximab to standard therapy for ANCAassociated vasculitis," Nephron, vol. 117, no. 2, pp. c89-c97, 2011.

[46] S. Laurino, A. Chaudhry, A. Booth, G. Conte, and D. Jayne, "Prospective study of TNF $\alpha$ blockade with adalimumab in ANCA-associated systemic vasculitis with renal involvement," Nephrology Dialysis Transplantation, vol. 25, no. 10, pp. 33073314, 2010.

[47] J. H. Stone, P. A. Merkel, R. Spiera et al., "Rituximab versus cyclophosphamide for ANCA-associated vasculitis," The New England Journal of Medicine, vol. 363, no. 3, pp. 221-232, 2010.

[48] C. Roubaud-Baudron, C. Pagnoux, N. Méaux-Ruault et al., "Rituximab maintenance therapy for granulomatosis with polyangiitis and microscopic polyangiitis," Journal of Rheumatology, vol. 39, no. 1, pp. 125-130, 2012.

[49] T. Sakane, M. Takeno, N. Suzuki, and G. Inaba, "Behçet's disease," The New England Journal of Medicine, vol. 341, no. 17, pp. 1284-1291, 1999.

[50] International Study Group for Behçet's Disease, "Criteria for diagnosis of Behçet's disease," The Lancet, vol. 335, no. 8697, pp. 1078-1080, 1990.

[51] H. Yazici, I. Fresko, and S. Yurdakul, "Behçet's syndrome: disease manifestations, management, and advances in treatment," Nature Clinical Practice Rheumatology, vol. 3, no. 3, pp. 148-155, 2007.

[52] S. Sahin Ozgun, R. Lawrence, H. Direskeneli, V. Hamuryudan, H. Yazici, and T. Akoglu, "Monocyte activity in Behçet's disease," British Journal of Rheumatology, vol. 35, no. 5, pp. 424-429, 1996.

[53] C. Evereklioglu, H. Er, Y. Türköz, and M. Cekmen, "Serum levels of TNF-alpha, sIL-2R, IL-6, and IL-8 are increased and associated with elevated lipid peroxidation in patients with Behçet's disease," Mediators of Inflammation, vol. 11, no. 2, pp. 87-93, 2002.

[54] S. Muñoz-Fernández, V. Hidalgo, J. Fernández-Melón, A. Schlincker, and E. Martín-Mola, "Effect of infliximab on threatening panuveitis in Behçet's disease," The Lancet, vol. 358, no. 9293, p. 1644, 2001.

[55] A. Arida, K. Fragiadaki, E. Giavri, and P. P. Sfikakis, "Anti-TNF agents for Behçet's disease: analysis of published data on 369 patients," Seminars in Arthritis \& Rheumatism, vol. 41, no. 1, pp. 61-70, 2011.

[56] A. A. Okada, H. Goto, S. Ohno, and M. Mochizuki, "Multicenter study of infliximab for refractory uveoretinitis in Behcet disease," Archives of Ophtalmology, vol. 130, no. 5, pp. 592-598, 2012.

[57] P. P. Sfikakis, P. H. Kaklamanis, A. Elezoglou et al., "Infliximab for recurrent, sight-threatening ocular inflammation in Adamantiades-Behçet disease," Annals of Internal Medicine, vol. 140, no. 5, pp. 404-406, 2004.

[58] S. Ohno, S. Nakamura, S. Hori et al., "Efficacy, safety, and pharmacokinetics of multiple administration of infliximab in Behçet's disease with refractory uveoretinitis," Journal of Rheumatology, vol. 31, no. 7, pp. 1362-1368, 2004.

[59] M. Accorinti, M. P. Pirraglia, M. P. Paroli, R. Priori, F. Conti, and P. Pivetti-Pezzi, "Infliximab treatment for ocular and extraocular manifestations of Behçet's disease," Japanese Journal of Ophthalmology, vol. 51, no. 3, pp. 191-196, 2007.

[60] S. Tognon, G. Graziani, and R. Marcolongo, "Anti-TNF- $\alpha$ therapy in seven patients with Behçet's uveitis: advantages and controversial aspects," Annals of the New York Academy of Sciences, vol. 1110, pp. 474-484, 2007.

[61] I. Tugal-Tutkun, A. Mudun, M. Urgancioglu et al., "Efficacy of infliximab in the treatment of uveitis that is resistant to treatment with the combination of azathioprine, cyclosporine, and corticosteroids in Behçet's disease: an open-label trial," Arthritis \& Rheumatism, vol. 52, no. 8, pp. 2478-2484, 2005.

[62] N. Markomichelakis, E. Delicha, S. Masselos, and P. P. Sfikakis, "Intravitreal infliximab for sight-thretening relapsing uveitis in Behcet disease : a pilot study in 15 patients," The American Journal of Ophtalmology, vol. 154, no. 3, pp. 534-554, 2012.

[63] D. Perra, M. A. Alba, J. L. Callejas et al., "Adalimumab for the treatment of Behcet's disease : experience in 19 patients," Rheumatology, vol. 51, no. 10, pp. 1825-1831, 2012.

[64] N. R. Benitah, L. Sobrin, and G. N. Papaliodis, "The use of biologic agents in the treatment of ocular manifestations of Behçet's disease," Seminars in Ophthalmology, vol. 26, no. 4-5, pp. 295-303, 2011.

[65] M. Mesquida, M. Victoria Hernàndez, V. Llorenç et al., "Behçet disease-associated uveitis successfully treated with golimumab," Ocular Immunology and Inflammation, vol. 21, no. 2, pp. 160$162,2013$.

[66] M. Melikoglu, I. Fresko, C. Mat et al., "Short-term trial of etanercept in Behçet's disease: a double blind, placebo controlled study," Journal of Rheumatology, vol. 32, no. 1, pp. 98-105, 2005.

[67] S. Iwata, K. Saito, K. Yamaoka et al., "Effects of anti-TNF$\alpha$ antibody infliximab in refractory entero-Behçet's disease," Rheumatology, vol. 48, no. 8, pp. 1012-1013, 2009.

[68] C. de Cassan, B. de Vroey, C. Dussault, E. Hachulla, S. Buche, and J.-F. Colombel, "Successful treatment with adalimumab in a familial case of gastrointestinal Behçet's disease," Journal of Crohn's \& Colitis, vol. 5, no. 4, pp. 364-368, 2011.

[69] H. Kikuchi, K. Aramaki, and S. Hirohata, "Effect of infliximab in progressive Neuro-Behçet's syndrome," Journal of the Neurological Sciences, vol. 272, no. 1-2, pp. 99-105, 2008.

[70] A. Giardina, A. Ferrante, F. Ciccia, M. Vadalà, E. Giardina, and G. Triolo, "One year study of efficacy and safety of infliximab in the treatment of patients with ocular and neurological Behçet's disease refractory to standard immunosuppressive drugs," Rheumatology International, vol. 31, no. 1, pp. 33-37, 2011.

[71] J. Belzunegui, L. López, I. Paniagua, J. J. Intxausti, and O. Maíz, "Efficacy of infliximab and adalimumab in the treatment of a patient with severe neuro-Behçet's disease," Clinical and Experimental Rheumatology, vol. 26, no. 4, supplement 50, pp. S133-S134, 2008. 
[72] J. E. Alty, T. M. Monaghan, and J. M. Bamford, "A patient with neuro-Behçet's disease is successfully treated with etanercept: further evidence for the value of TNF $\alpha$ blockade," Clinical Neurology and Neurosurgery, vol. 109, no. 3, pp. 279-281, 2007.

[73] P. Leccese, L. Latanza, S. D’Angelo, A. Padula, and I. Olivieri, "Efficacy of switching to adalimumab in a patient with refractory uveitis of Behçet's disease to infliximab," Clinical and Experimental Rheumatology, vol. 29, no. 4, supplement 67, p. S93, 2011.

[74] J. A. Singh, G. A. Wells, R. Christensen et al., "Adverse effects of biologics: a network meta-analysis and Cochrane overview," Cochrane Database of Systematic Reviews, vol. 16, no. 2, Article ID CD008794, 2011.

[75] C. Salliot, L. Gossec, A. Ruyssen-Witrand et al., "Infections during tumour necrosis factor- $\alpha$ blocker therapy for rheumatic diseases in daily practice: a systematic retrospective study of 709 patients," Rheumatology, vol. 46, no. 2, pp. 327-334, 2007.

[76] A. A. den Broeder, L. A. B. Joosten, T. Saxne et al., "Long term anti-tumour necrosis factor $\alpha$ monotherapy in rheumatoid arthritis: effect on radiological course and prognostic value of markers of cartilage turnover and endothelial activation," Annals of the Rheumatic Diseases, vol. 61, no. 4, pp. 311-318, 2002.

[77] E. C. Keystone, M. H. Schiff, J. M. Kremer et al., "Once-weekly administration of $50 \mathrm{mg}$ etanercept in patients with active rheumatoid arthritis: results of a multicenter, randomized, double-blind, placebo-controlled trial," Arthritis \& Rheumatism, vol. 50, no. 2, pp. 353-363, 2004.

[78] E. C. Keystone, A. F. Kavanaugh, J. T. Sharp et al., "Radiographic, clinical, and functional outcomes of treatment with adalimumab (a human anti-tumor necrosis factor monoclonal antibody) in patients with active rheumatoid arthritis receiving concomitant methotrexate therapy: a randomized, placebocontrolled, 52-week trial," Arthritis \& Rheumatism, vol. 50, no. 5, pp. 1400-1411, 2004.

[79] E. W. St.Clair, D. M. F. M. van der Heijde, J. S. Smolen et al., "Combination of infliximab and methotrexate therapy for early rheumatoid arthritis: a randomized, controlled trial," Arthritis \& Rheumatism, vol. 50, no. 11, pp. 3432-3443, 2004.

[80] J. Askling and W. Dixon, "The safety of anti-tumour necrosis factor therapy in rheumatoid arthritis," Current Opinion in Rheumatology, vol. 20, no. 2, pp. 138-144, 2008.

[81] J. Keane, S. Gershon, R. P. Wise et al., "Tuberculosis associated with infliximab, a tumor necrosis factor $\alpha$-neutralizing agent," The New England Journal of Medicine, vol. 345, no. 15, pp. 1098$1104,2001$.

[82] J. Askling, R. F. van Vollenhoven, F. Granath et al., "Cancer risk in patients with rheumatoid arthritis treated with anti-tumor necrosis factor $\alpha$ therapies: does the risk change with the time since start of treatment?" Arthritis \& Rheumatism, vol. 60, no. 11, pp. 3180-3189, 2009.

[83] F. Wolfe and K. Michaud, "The effect of methotrexate and antitumor necrosis factor therapy on the risk of lymphoma in rheumatoid arthritis in 19,562 patients during 89,710 personyears of observation," Arthritis \& Rheumatism, vol. 56, no. 5, pp. 1433-1439, 2007.

[84] F. Wolfe and K. Michaud, "Biologic treatment of rheumatoid arthritis and the risk of malignancy: analyses from a large US observational study," Arthritis \& Rheumatism, vol. 56, no. 9, pp. 2886-2895, 2007.

[85] J. Kelsall, P. Rogers, G. Galindo, and M. A. de Vera, "Safety of infliximab treatment with rheumatoid arthritis in a realworld clinical setting : description and évaluation of infusion reactions," Journal of Rheumatology, vol. 39, no. 8, pp. 1539-1545, 2012.

[86] L. de Rycke, D. Baeten, E. Kruithof, F. van den Bosch, E. M. Veys, and F. de Keyser, "The effect of TNFalpha blockade on the antinuclear antibody profile in patients with chronic arthritis: biological and clinical implications," Lupus, vol. 14, no. 12, pp. 931-937, 2005.

[87] N. Mohan, E. T. Edwards, T. R. Cupps et al., "Demyelination occurring during anti-tumor necrosis factor alpha therapy for inflammatory arthritides," Arthritis \& Rheumatism, vol. 44, no. 12, pp. 2862-2869, 2001. 


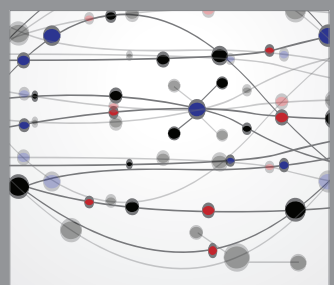

The Scientific World Journal
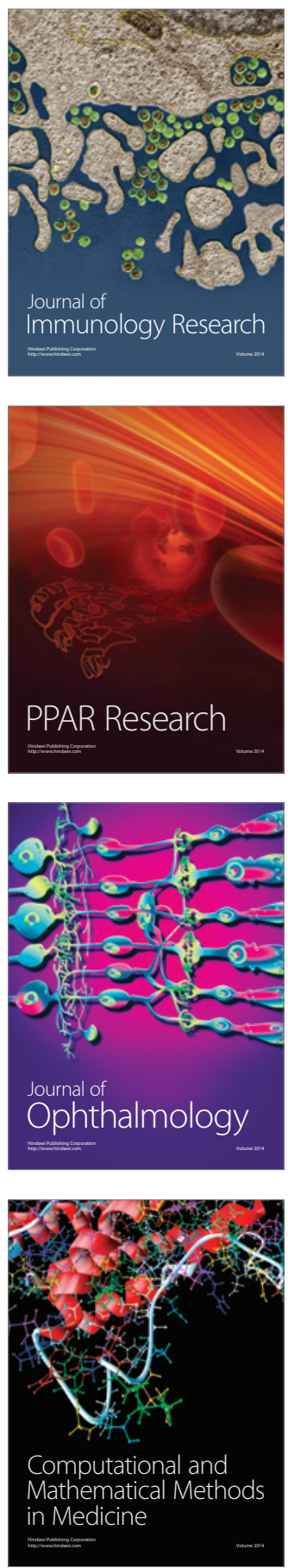

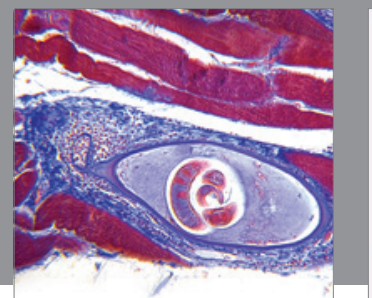

Gastroenterology

Research and Practice
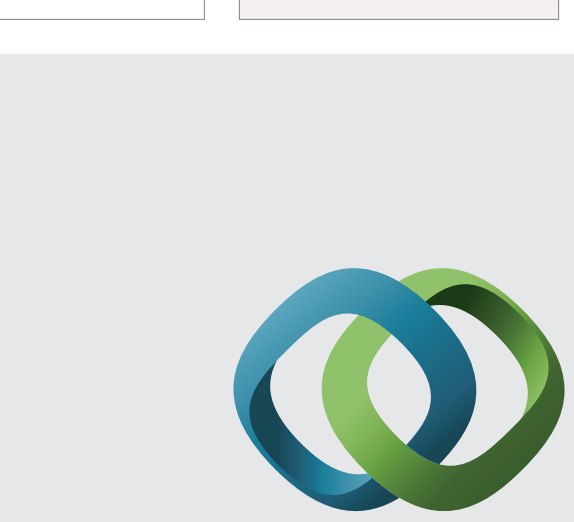

\section{Hindawi}

Submit your manuscripts at

http://www.hindawi.com
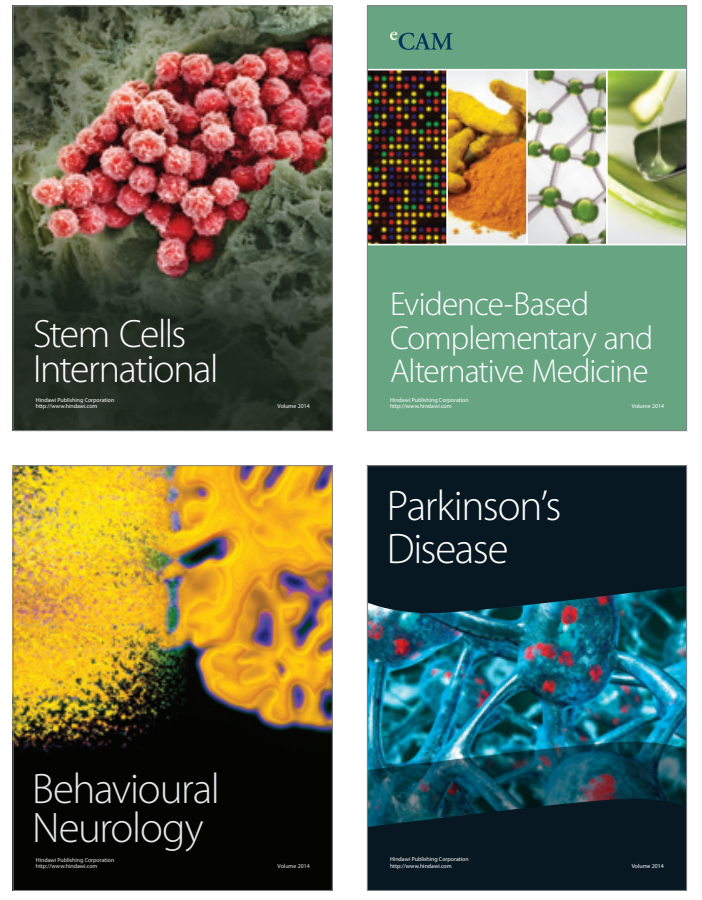
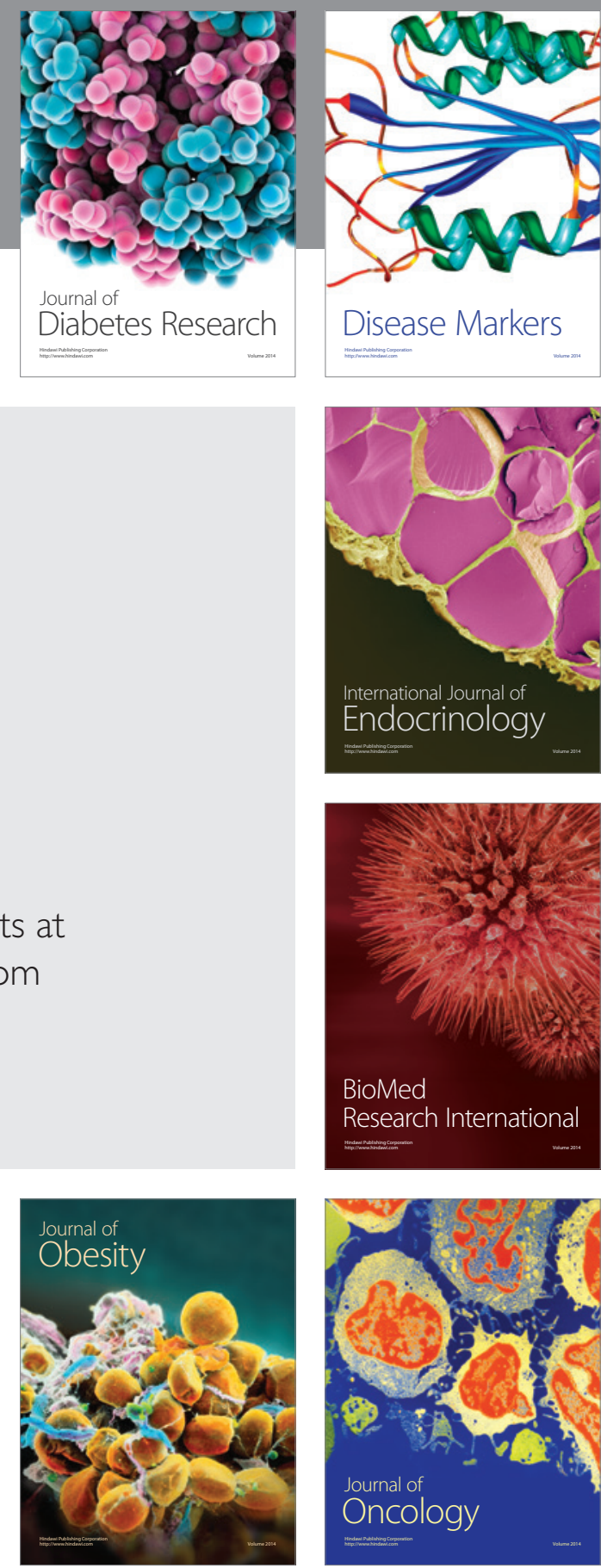

Disease Markers
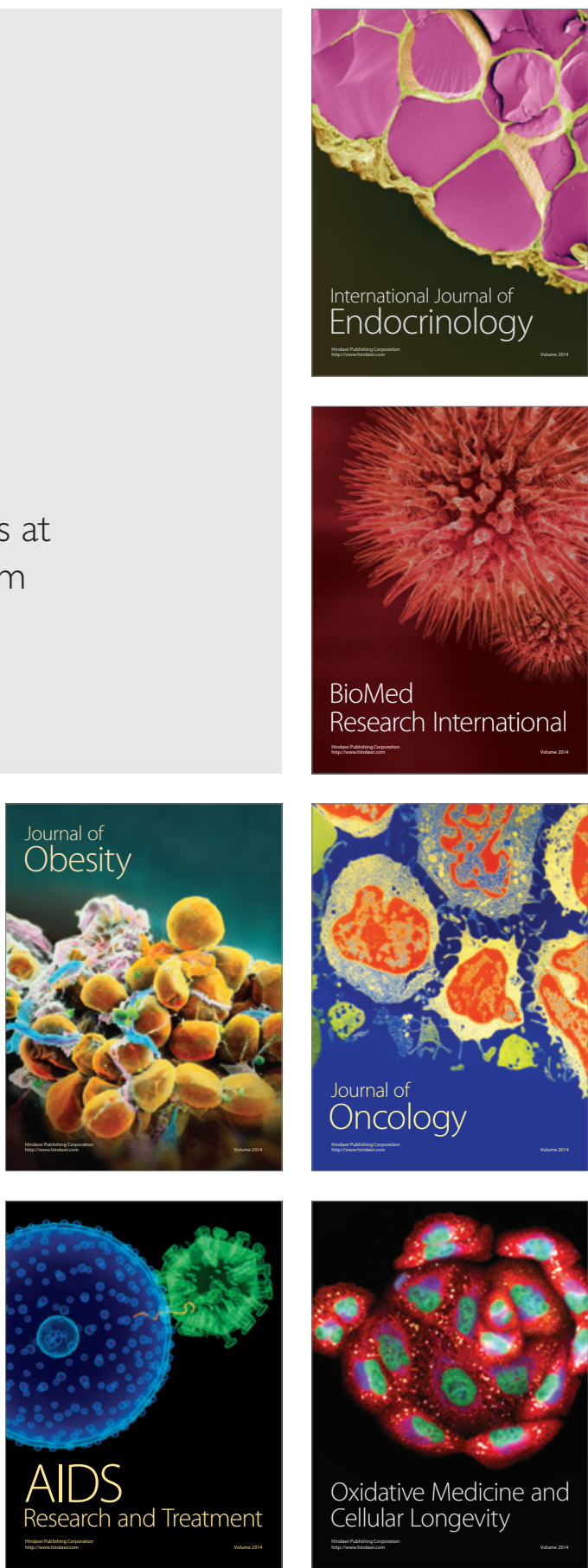